\title{
Research on the Teaching Academic Ability Effect in College English Class
}

\author{
Zhou Yun \\ School of Foreign Languages, Yuxi Normal University, Yuxi, Yunnan 653100 \\ hunter2011@foxmail.com
}

Keywords: Academic teaching, Effective teaching, English classroom, Affect.

\begin{abstract}
Teaching academic is a ability of university teachers and scholars based on the premise of teaching theoretical knowledge and practical knowledge. As a college English teacher, based on years of work experience, this paper explores the role of teaching academic ability in college English class, namely: expanding the scope of academic, prompting teachers rationally understanding for university teaching, prompting teachers to reflect scientific and study education, promoting teacher quality improvement, guiding teachers teaching practice, ensuring school to complete teaching tasks.
\end{abstract}

\section{Basic understanding for teaching academic ability}

Depending on the understanding and awareness of domestic and foreign scholars for teaching academic, this paper believes that university teachers' teaching academic mainly reflected in the following aspects:

First, in-depth understanding for teaching. University teaching is complex and difficult to correctly acknowledge, teachers should perceive and make sense the vision with academic teaching, using academic norms to carry out teaching. Therefore, teaching academic is deep and thorough understanding of teachers for teaching activities.

Second, the level of understanding for the education department of professional knowledge and education subject knowledge. As an academic career, teaching begins from his own understanding of things. Teachers must immerse themselves in the professional field of knowledge acquiring knowledge of the teaching subjects. Only with a broad range and intellectually deepened, can their teaching be achieved many gains. Meanwhile, if the teacher have no advanced educational philosophy as a pilot, no master system teaching theory, and practice and teaching does not have the relevant knowledge, the teaching activities is also difficult to achieve results. Thus, teaching academic is deep professional knowledge and extensive education academic knowledge.

Third, the ability manifested in the teaching activities. This capability includes: the ability to attract students to actively participate in teaching activities; the ability to encourage students to think and innovative thinking; the ability to utilize network and multimedia technology to improve teaching efficiency and effectiveness; the ability to the actual situation of the re-creation of teaching content, teaching students to better grasp of the content, which is mainly manifested as operational capacity, organizational skills, adapting ability, innovation and reflection ability.

Fourth, the results achieved in the practice and teaching research teaching. This includes a summary of the experience of teachers for teaching practices and the innovation for theoretical research teaching. Touchstone of university teaching is not to teach great truths, but the method to teach great truths. If teachers' activities have no certain of outcome, the teaching will lose its fundamental meaning. Trial and error in teaching practice and innovation in theoretical study are to achievements in teaching, to improve teaching quality in order to better carry out teaching.

In summary, the author believes the university teaching academic is university teachers' systematic and specialized knowledge about teaching, and it specific performance on teaching understanding, knowledge, ability and results obtained. 


\section{Effect of teaching academic ability in college English class}

Expand the scope of academic. The introduction of the teaching academic concept can change university teachers' academic concept and expand the academic scope. The traditional concept always thought that at the university, only science can only be called academic and only the scientific research is th academic research. This erroneous tendency severely restricts the development of higher education and the future direction of academic, which is contrary the traditional concept of university development and basic functions. Since Ernest $\cdot \mathrm{L} \cdot$ Boyer made a new definition for the concept of academic, people have a new vision for academic, understanding that teaching academic and exploration academic, integration academic and application academic together constituted the new academic areas, thus expanding and extending the scope of the academic, Teaching academic, i.e. imparting knowledge, building capacity and developing personality.

To promote teacher rational understanding university English class. University teachers subject to various restrictions in recognition of university teaching time, such as historical background, development of university teaching and their own cognitive level of the university. In the past, people called teachers pedagogue, I.e. spread artisan knowledge. The introduction of academic teaching makes people know rationally university teachers, recognizing artisans and teachers are essentially different. Craftsmen engaged in a simple job with procedures, fewer creativity, although the process is skilled, but very with little wisdom and academic components. Teachers teaching are creative and have a strong academic, reaching a high state. Craftsmen gave apprentice means of livelihood, but the teacher education students are "man to man Machine". This coverage is far greater than the scope of the general connotation of artisan work, people processed to become ideals, morality, culture, and discipline of the new generation, focusing on all-round development. Thus, university teachers are not pedagogue. University education can not simply be understood as a repetitive operating activities. In fact, the university teaching is an academic activities. Teaching academic can promote faculty rationally to understand university teaching from an academic point of view.

Encourage teachers to scientifically reflect and teaching research. Teaching is the process of applying educational theory and technical achievements, and tends to take "applied" theory applied to education research or teaching practice. Emphasize teaching practice reflection, timely using the theory and technological achievements to enhance education teaching practice guidance and control. Scientific reflection and research on the nature of teaching means that teachers teaching ideas constantly updated, and it is improved in teaching methods to improve teaching ability. Faculty reflection and research on teaching must have theory as a basis, teaching academic laying a solid theoretical foundation, ensure that teachers teaching science to reflect and study.

Enrich the theoretical basis of teaching, improve teacher quality. Teaching academic can enrich the theoretical basis of teaching, and offer effective teaching theoretical basis or condition. University Teachers' Specialization is a process that teacher grow from novice to expert teachers, and teaching academic is an important dimension of research faculty specialization. Teaching academic not only provides theoretical support. For faculty rational knowledge and reflections on teaching science, but also lay a good foundation for the university teachers' specialization and quality. University teachers' professional accomplishment is formed through a variety of ways and socio-cultural constant contact to understand their own status in the system. To improve. University teachers' specialization and quality not only needs scientific research capability, but also needs teaching academic level. Improving teacher specialization and quality is inseparable from its academic research and teaching to enhance teaching itself, with teachers teaching academic specialization are often easy to implement.

Guide teachers teaching practice. Theoretical research is to guide practice, university teachers' teaching academic can guide the teaching practice, making teaching follow teaching characteristics in the teaching of law, promoting successful teaching, reducing teaching mistakes, timely adjust or improve teaching and making teaching practice more effective. First, it can promote successful teaching. Among the factors affecting the success of teaching, teaching academic is a factor can not 
be ignored. The teachers with teaching scholarship is often handy in teaching, and the teaching effect is much better than the average teacher. Second, it can reduce teaching mistakes. In the teaching process, there will be inevitably a variety of negligence and accident, and its causes is nothing less than inadequate preparation of teaching, no deep teaching skills and, poor teaching concentration. However, academic teaching an make these possibilities bottoming out. Again, it may be time to adjust or improve teaching. Teaching guidance adjustments or improvements is inseparable with theory. Teachers with academic teaching can better grasp the teaching practice than the average teacher to ensure the orderly teaching conduct.

To ensure the completion of the school teaching task. Teaching is the central task of the school, personnel training is the primary academic responsibility of the university teachers. Teaching academic is the fundamental guarantee for schools to better complete the task of teaching. In the "big teaching theory", the Comenius pointed out at the outset, to optimize teaching, improve teaching quality, we must seek and find a method of teaching so that teachers can be less teaching, but students can learn more. Teachers teaching academic is to optimize teaching, improve teaching quality assurance, so that society is full of light and peace, so that students are full of hope for a better life. University personnel training process is actually the process of pushing humanity toward the desired preset. Humans continue to go beyond the reality of the moment in the transformation of the objective world and the subjective world. In he process humans continue to go beyond present reality and transform the objective world and the subjective world, it is achieving leap from the realm of necessity to the realm of freedom. As an important way and means of personnel training, the role of university teaching is self-evident, and university teachers teaching academic provides a scientific basis for effective teaching, promoting the rationality of teaching practice, which can ensure that schools complete the task of teaching, and that to improve the quality of teaching and training high-quality personnel tasks.

\section{Conclusion}

Researches on the university teachers teaching academic has obvious practical significance, which can provide an effective reference for college English teaching. The value of university teaching academic is to expand the range of academic, prompting teachers rationally understanding university teaching, prompting teachers to reflect scientific and research education. Starting from English class, this paper discusses the importance of teaching academic from the perspective of six dimensions, that is expanding the scope of academic, promoting teacher rational understanding university English class, encouraging teachers to scientifically reflect and teaching research, enriching the theoretical basis of teaching, improve teacher quality, guiding teachers teaching practice and ensuring the completion of the school teaching task.

\section{References}

[1] G.L. Zhou, H.Q. Ma. Teaching academic skills: a new framework for faculty development and evaluation. Educational Research, 2013,08: 37-47.

[2] J.H. Shi, Xu sweet, Y.F. Li. Study on the University Teachers' Teaching Academic Situation Analysis Based on the Survey 44 universities. Higher Education Research, 2011,12: 52-66.

[3] L.H. Lv. Teacher Development Mechanism and Implications academic university teaching. Higher Education Research, 2009,08: 83-88.

[4] H. Yin. Faculty Academic teaching situation and countermeasures to increase the. Hunan University, 2008.

[5] C.Y. Han. Update university teachers teaching the concept of academic research. Southwest University, 2013.

[6] H. Li. Boyer Teaching Scholarship Research and Enlightenment. Henan University, 2010. 